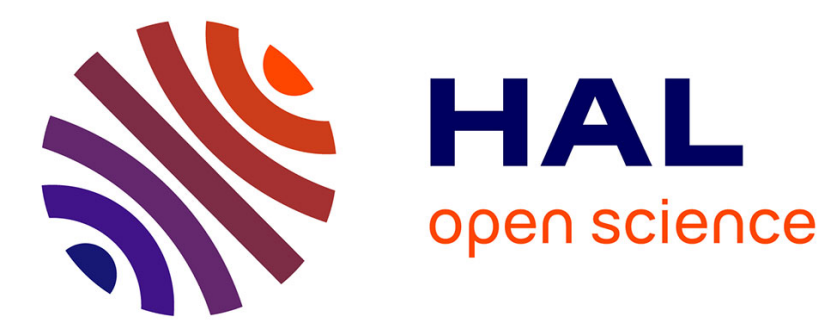

\title{
Constraints on magma transfers and structures involved in the 2003 activity at Piton de La Fournaise from displacement data
}

\author{
Aline Peltier, T Staudacher, Patrick Bachèlery
}

\section{To cite this version:}

Aline Peltier, T Staudacher, Patrick Bachèlery. Constraints on magma transfers and structures involved in the 2003 activity at Piton de La Fournaise from displacement data. Journal of Geophysical Research, 2007, 112, pp.B03207. 10.1029/2006JB004379 . insu-01285077

\section{HAL Id: insu-01285077 https://hal-insu.archives-ouvertes.fr/insu-01285077}

Submitted on 8 Mar 2016

HAL is a multi-disciplinary open access archive for the deposit and dissemination of scientific research documents, whether they are published or not. The documents may come from teaching and research institutions in France or abroad, or from public or private research centers.
L'archive ouverte pluridisciplinaire HAL, est destinée au dépôt et à la diffusion de documents scientifiques de niveau recherche, publiés ou non, émanant des établissements d'enseignement et de recherche français ou étrangers, des laboratoires publics ou privés. 


\title{
Constraints on magma transfers and structures involved in the 2003 activity at Piton de La Fournaise from displacement data
}

\author{
A. Peltier, ${ }^{1,2}$ T. Staudacher, ${ }^{2}$ and P. Bachèlery ${ }^{1}$ \\ Received 6 March 2006; revised 12 September 2006; accepted 26 September 2006; published 24 March 2007.
}

[1] Piton de La Fournaise (Réunion Island) had shown 8 months of high activity during 2003, including four eruptions and one intrusion. The monitoring networks, provided by the Volcanological Observatory of Piton de La Fournaise, show two different kinds of behavior: strong and rapid deformations linked with the magma injections and a slight continuous intereruptive inflation of the summit area. Inversed modeling based on the deformation data, using a three-dimensional elastostatic boundary element code, combined with seismicity provides new insights into the volcanic feeding system involved in the 2003 activity. (1) The 2003 eruptions are fed from a pressurized magma chamber located beneath the summit at $300 \mathrm{~m}$ above sea level. (2) A vertical path was activated between the magma chamber and the surface during the December 2002 collapse, allowing the magma to rise into it and leading to the initial summit eruption in May 2003. (3) The August and September 2003 lateral eruptions had been fed by dikes intruding along the same vertical pathway, at an estimated velocity of 1.1 to $1.3 \mathrm{~m} / \mathrm{s}$ before intruding the flank into the rift zones at a velocity of 0.2 to $0.8 \mathrm{~m} / \mathrm{s}$. This last point suggests a strong structural control on the dike pathway.

Citation: Peltier, A., T. Staudacher, and P. Bachèlery (2007), Constraints on magma transfers and structures involved in the 2003 activity at Piton de La Fournaise from displacement data, J. Geophys. Res., 112, B03207, doi:10.1029/2006JB004379.

\section{Introduction}

[2] The emplacement of dikes within a volcanic edifice has been the subject of several studies in recent decades. Several models of dike intrusions leading to an eruption have been proposed for Kilauea (Hawaii) [Cervelli et al., 2002], Etna (Sicily) [Bonaccorso et al., 2002] and Piton de La Fournaise (PdF) (La Réunion, Indian Ocean) [Battaglia and Bachèlery, 2003; Froger et al., 2004; Fukushima et al., 2005]. The great majority of these studies strictly focused on the dike geometry related to one eruption, without considering the previous events and sometimes without evaluating the source of the magma and the triggering processes. It is however of major interest to focus on a series of several volcanic crises to understand the initial processes driving magma toward the surface and to define and interpret the evolution in time of the eruptive style of a volcano.

[3] The cycle of high activity at PdF in 2003, with four eruptions (May, August, September, and December) and one intrusion (November), provides an extensive set of deformation and seismic data in a short time span. All 2003 eruptions occurred inside the Enclos Fouqué caldera

\footnotetext{
${ }^{1}$ Laboratoire des Sciences de la Terre de l'Université de la Réunion, UMR7154, Saint Denis, France.

${ }^{2}$ Observatoire Volcanologique du Piton de la Fournaise, UMR7154, La Plaine des Cafres, France.
}

Copyright 2007 by the American Geophysical Union. 0148-0227/07/2006JB004379\$09.00
(Figures 1 and 2). The May and December eruptions were located inside the Dolomieu summit crater. The August eruption started in the Bory crater, but the main activity was located along fissures opened on the northern flank rift zone oriented $\mathrm{N} 10^{\circ} \mathrm{E}$, while the September eruption occurred on the south flank of the summit cone along the rift zone oriented $\mathrm{N} 170^{\circ} \mathrm{E}$ (Figures 1 and 2 ). The location of the magma chamber and the geometry of the plumbing system feeding these eruptions are still debated. Lénat and Bachèlery [1990] suggest that magma storage can take place just beneath the summit crater at shallow depth $(0-1500 \mathrm{~m}$ above sea level) in the form of small interconnected pockets and dikes. Recent seismic data are more consistent with the existence of a single magma chamber situated at sea level inferred from the presence of a low-velocity zone beneath the summit [Nercessian et al., 1996]. The seismic swarms associated with magma intrusions were located above this zone (Figure 3). In both concepts, interconnected magma pockets or single magma chamber, such a shallow magma storage system must be fed from deeper levels. Indications for such feeding exist for the 1977 and 1998 eruptions [Bachèlery, 1999]. The large 1998 eruption was preceded in 1997 by a "seismic crisis" $15 \mathrm{~km}$ beneath the "Plaine des Sables" (Figure 1), and a preeruptive seismic swarm rooted at $5 \mathrm{~km}$ below sea level, that migrated toward the surface [Battaglia et al., 2005].

[4] Preeruptive overpressures in the shallow magma chamber exert stress on the surrounding bed rock, generating seismic events and long-term ground deformation of the 

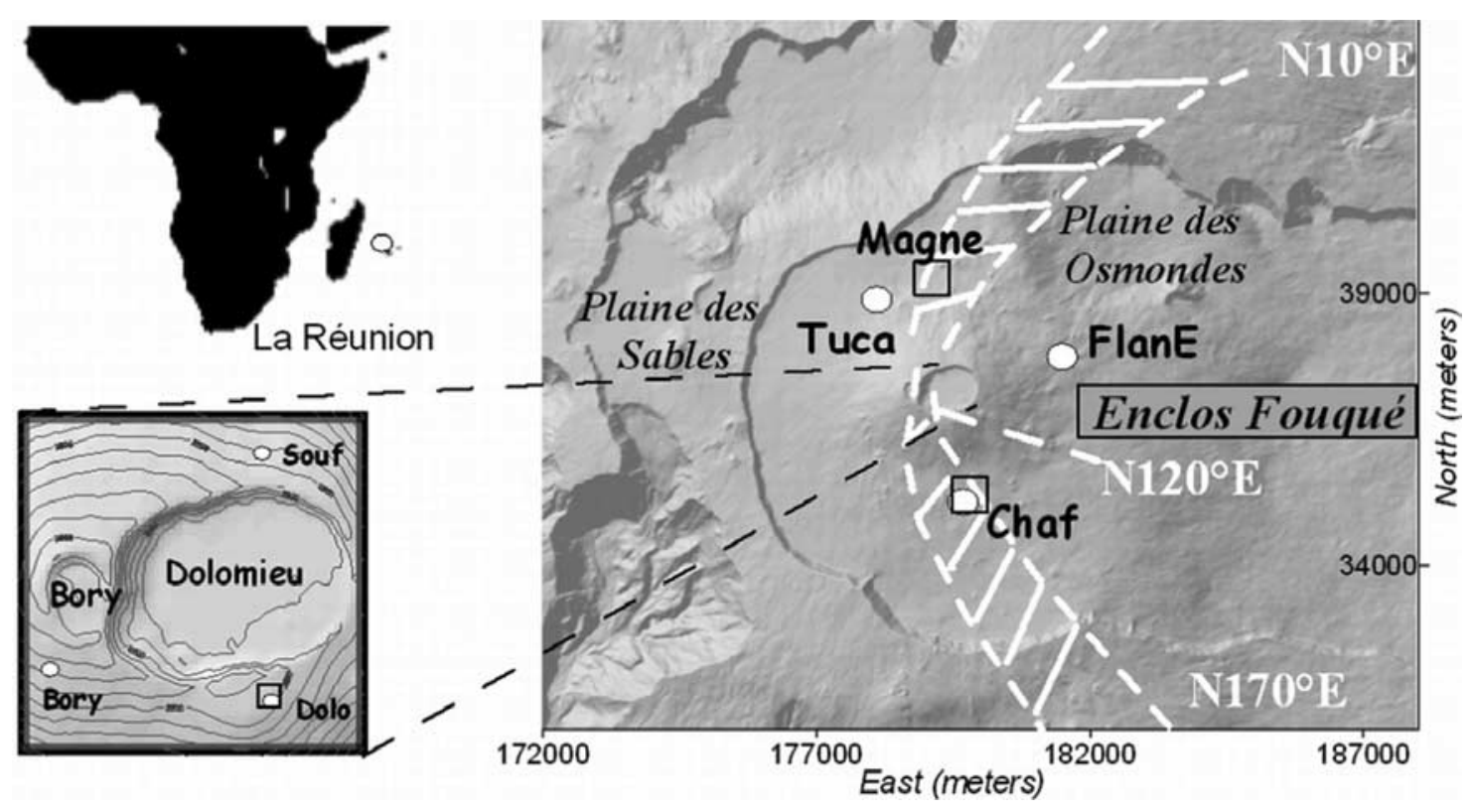

Figure 1. Structural map of Piton de la Fournaise volcano (Gauss Laborde Reunion coordinates). The rift zones are indicated by white dashed lines. The black squares and white dots indicate the locations of extensometers and tiltmeters, respectively.

volcano. Both, intereruptive behavior and eruptive mechanisms, were modeled with a three-dimensional (3-D) elastostatic boundary element code that takes into account topography, fractures and magma chamber geometries [Cayol and Cornet, 1997, 1998]. Models (dikes and magma chamber) of the deformation source were derived by an inversion method using GPS and tiltmeter data. These models allow us to discuss the processes of magma supply to eruptions and intrusions and to identify links between eruptions and intrusion within this eruptive cycle.

\section{Deformation Networks}

[5] We focus our study on data recorded during 2003 by three deformation networks of the Volcanological Observatory of Piton de La Fournaise (OVPF): the tiltmeters, the extensometers, and the GPS networks.

[6] The tiltmeter network is composed of six stations (Figure 1); three are located around the summit craters and three others are located at the base of the summit cone. Each station is composed of two Blum-type pendulum tiltmeters [Blum et al., 1991], one orientated radially with respect to the summit, and the other tangentially. Measurements are performed every minute. The combination of the two tiltmeters, radial and tangential, gives the direction and amplitude of the tilt angles graphically represented as tilt vectors (Figure 2). The changes in orientation and amplitude allow us to evaluate the migration of the inflation source with time.

[7] The extensometer network of the OVPF included two stations at the base of the summit cone that were installed on small fractures opened along the main north-south axis of activity, one at "Chaf" on the southern axis and the second at "Magne" on the northern axis (Figure 1). Magne station was destroyed by the lava flows of the August 2003 eruption. Each extensometer station is composed of three components measuring every minute the relative displacement perpendicular to the fracture (opening component), parallel to the fracture (shearing component) but also the vertical movement across the fracture (vertical component).

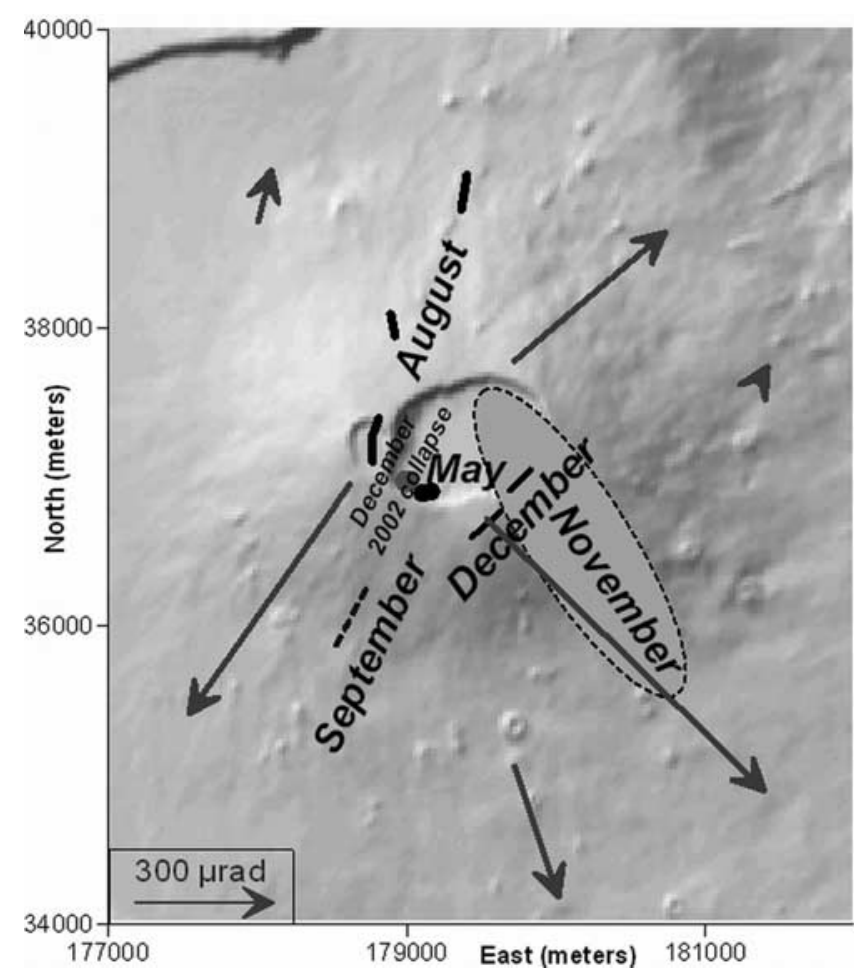

Figure 2. Location of the fissures associated with the studied eruptions and approximate location of the November intrusion (Gauss Laborde Reunion coordinates). Vectors represent tilt variations between May and December 2003 are oriented in direction of the slope increase. 

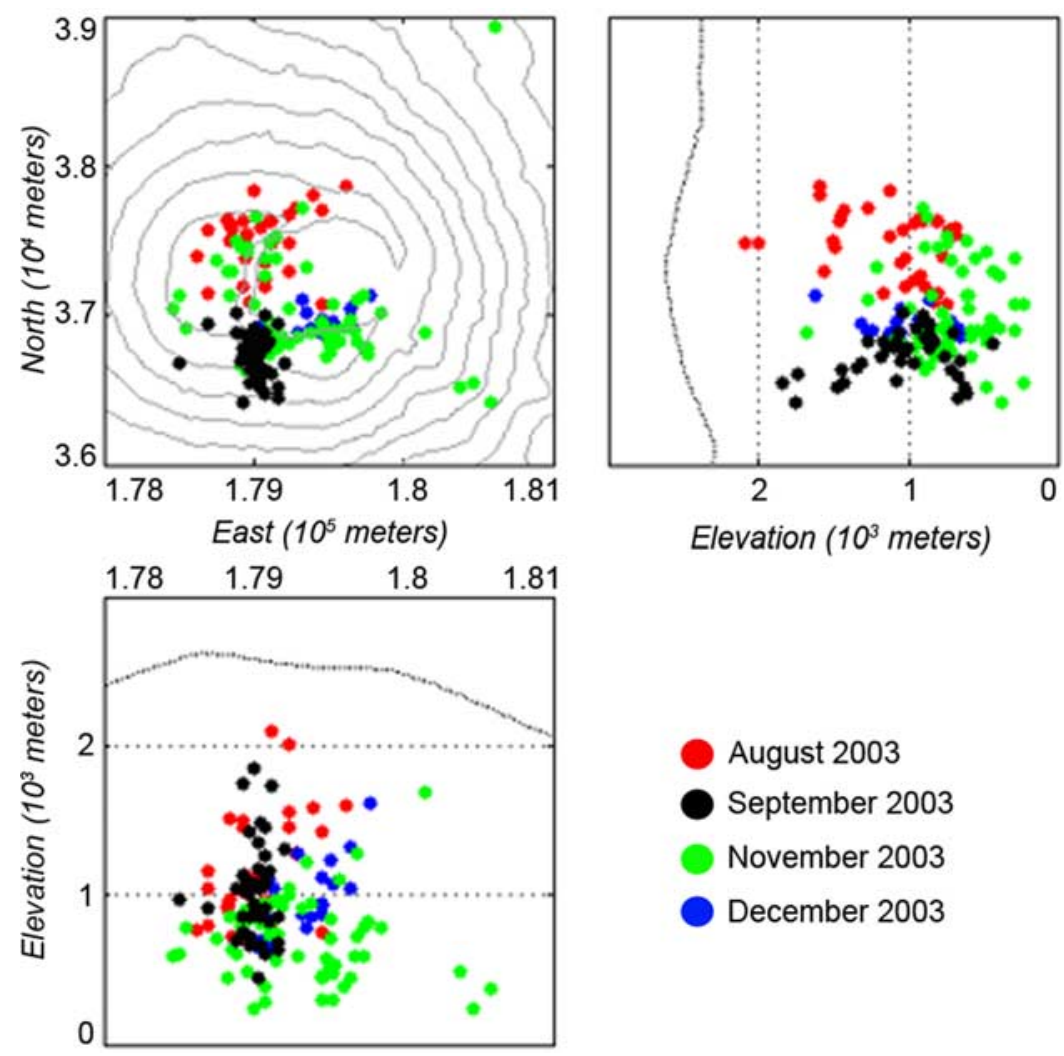

Figure 3. Location of some earthquakes hypocenters related to the magma injections of 2003 (Gauss Laborde Reunion coordinates).

Another three component station, "Dolo," is installed on a summit tangential fissure on the south rim of the Dolomieu crater (Figure 1).

[8] At the beginning of 2003, only one permanent GPS station operated on the volcano at "Souf" summit station. The GPS used is so-called "Ashtech Zextrem" installed on a stainless steel rod cemented in the bedrock. The GPS network is also composed of about 80 benchmarks measured before and after each event.

\section{Description of Events and Data}

[9] During this period of high activity, we observed on all deformation networks a long-term and constant inflation (Figures 2 and 4) of the summit zone. This continuous inflation, accompanied by an increase in shallow seismicity (just above sea level) was only interrupted by the onset of the eruptions/intrusion (Figures 4 and 5). Only subtle summit deflations were observed during magma injections to the flank of PdF (Figure 4). The cumulative slope variation is shown in Figure 2. From March to December 2003 the inflation of the volcano reached $800 \mu \mathrm{rad}$ at tiltmeter Dolo, while the vertical uplift at permanent GPS summit station Souf reached $50 \mathrm{~cm}$ (Figure 4). Simultaneously, the extensometers showed a continuous opening of the fractures between eruptions (Figure 4). Tilt stations at the base of the volcano showed also a continuous summit inflation, but the amplitude of the signal is lower than on the summit station.

\subsection{May-June 2003 Eruption}

[10] The first eruption in 2003 began the 30 May by the opening of a fissure at the rim of the pit crater, formed on 23 December 2002 [Longré et al., 2006], in the southwestern part of the Dolomieu crater (Figure 2 and Table 1) and proceeded in four phases. The first one stopped after only two hours; however seismicity beneath the crater continued (Figure 5). No deflation was detected (Figure 4) and a strong degassing was observed. On 4 June, the eruption started again at the same site. After a short phreatic event, the second phase stopped on the evening of 6 June. The extensometer network continued to show an opening of fractures at Magne and Chaf (Figure 4) accompanied by earthquakes located around $400 \mathrm{~m}$ beneath the Dolomieu floor in the southwestern part of this crater. On 12 June, activity resumed within Dolomieu crater and the third phase continued until 15 June at the same site as the two previous ones. The last stage started on 21 June and ended on 7 July [Coppola et al., 2005].

[11] This summit eruption did not have a great impact on the tiltmeter and extensometer curve, which continued to show an increasing trend and indicating inflation behavior throughout and after this eruptive cycle (Figure 4).

\subsection{August 2003 Eruption}

[12] Between the end of the May-June and August eruptions, the northern border of Dolomieu crater was raised by about $3 \mathrm{~cm}$ and shifted to the east by about $3.5 \mathrm{~cm}$ (Figure 4). Twenty to sixty seismic events per day were recorded at the 


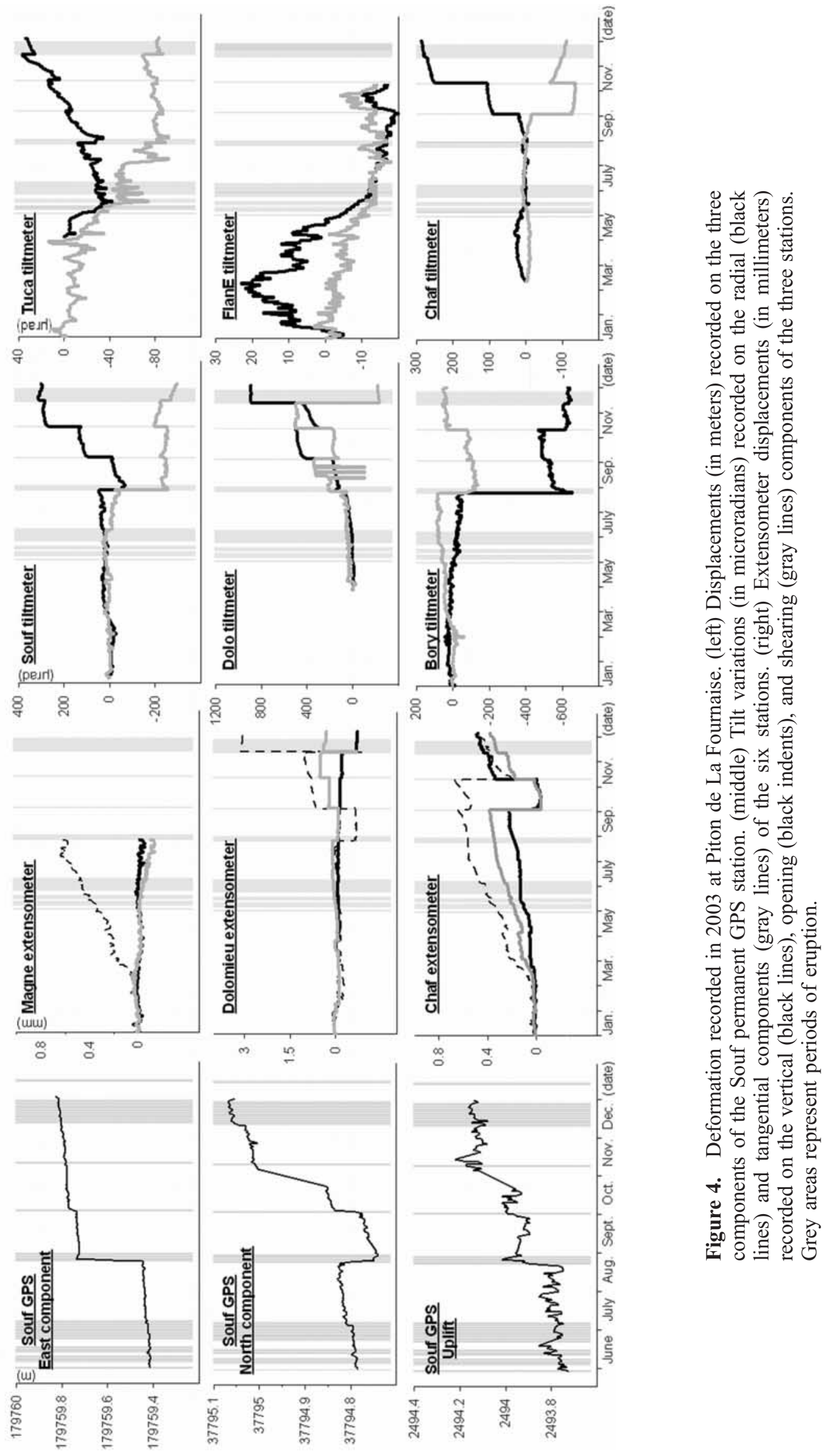




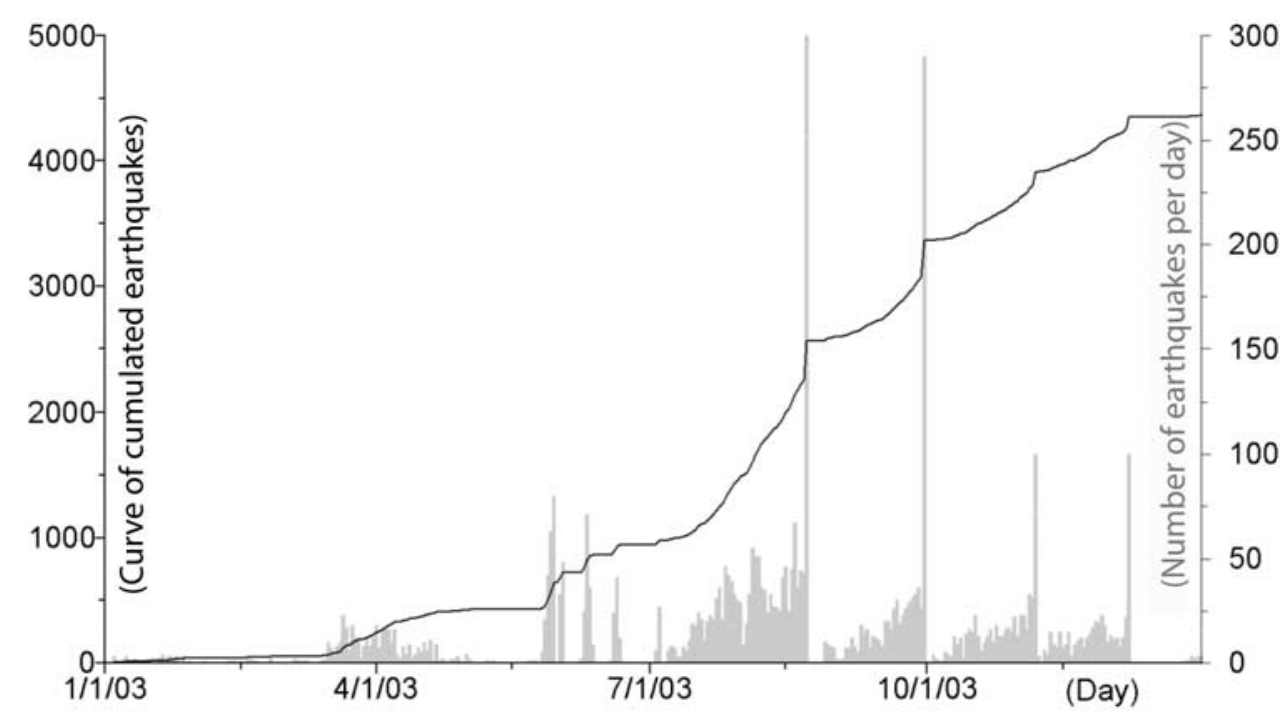

Figure 5. Annual cumulative number of volcano-tectonic events recorded at Piton de La Fournaise in 2003. The gray histogram represents the number of earthquakes per day.

end of July and in August (Figure 5) [Staudacher et al., 2004]. On 22 August at 1448 UTM, a "seismic crisis" started, with about 300 events within 152 min (Figure 5). These earthquakes were located beneath the NW rim of Dolomieu crater at about 500-1500 m above sea level (Figure 3). At 1455 UTM, tiltmeter data revealed that a dike propagated toward the surface. At first, the radial component at all summit stations steadily increased and in a second stage from 1515 UTM, the tilt gave clear signals of a flank intrusion (Figure 6 and Table 1). From 1630 UTM, the tilt vectors at "Bory" station rotated, showing a new inflation which reached a value of $200 \mu \mathrm{rad}$ at 1720 UTM when the first fissure in the Bory crater opened. After that, further seismic events were observed, and at 1810 UTM a second fissure opened at $2475 \mathrm{~m}$ altitude on the north flank of PdF. At 1930 UTM a third fissure opened lower on the northern flank (Figure 1). The eruptive activity was localized at $2150 \mathrm{~m}$ altitude, were a cone was formed. Eruption intensity increased from 25 until 27 August when the eruption stopped suddenly. Permanent GPS measurements at Souf station showed slight deflation during the eruption (Figure 4). Surface displacements measured between early August and early September on the 80 benchmarks of the GPS network (Figure 7) show $25 \mathrm{~cm}$ of uplift and $30 \mathrm{~cm}$ of eastward displacement of the NE part of the Dolomieu crater related to this eruption.

\subsection{September 2003 Eruption}

[13] During September, Tuca, Souf, Dolo and Chaf tiltmeter radial components increased by $30,57,45$, and $21 \mu \mathrm{rad}$, respectively, while the Chaf extensometer indicated continuous fracture opening (Figure 4). On 30 September at 1825 UTM, a "new seismic" crisis started, with 290 events located in a swarm beneath the southwest border of Dolomieu crater (Figure 3), and 65 min later tremor was recorded. Similar to August eruption and other flank eruptions at PdF [Peltier et al., 2005b], permanent tiltmeters revealed a dike propagation in two stages with a first vertical migration between 1835 and 1848 UTM under the Dolomieu crater followed by a lateral propagation to the south (Figure 6 and Table 1). A new eruptive fissure opened on the southern flank between 2330 and $2190 \mathrm{~m}$ altitude. Next morning, on 1 October at 0900 UTM, the seismic tremor disappeared. Surface displacements linked to this event had been measured by GPS immediately after the eruption underlining the eruption fissures pathways (Figure 7). After this event, the rate of shallow earthquakes increased again,

Table 1. Summary of 2003 Eruptions

\begin{tabular}{|c|c|c|c|c|c|c|}
\hline $\begin{array}{c}\text { Beginning of } \\
\text { Eruption }\end{array}$ & Location & $\begin{array}{c}\text { Altitude } \\
\text { of the } \\
\text { Eruptive } \\
\text { Fissure, m }\end{array}$ & $\begin{array}{c}\text { Seismic } \\
\text { Crisis } \\
\text { Duration, } \\
\text { min } \\
\end{array}$ & $\begin{array}{c}\text { Vertical } \\
\text { Injection } \\
\text { Duration, } \\
\text { min }\end{array}$ & $\begin{array}{c}\text { Lateral } \\
\text { Injection } \\
\begin{array}{c}\text { Duration, } \\
\text { min }\end{array} \\
\end{array}$ & $\begin{array}{l}\text { Emitted } \\
\text { Volume, } \\
10^{6} \mathrm{~m}^{3}\end{array}$ \\
\hline 30 May 2003 & southwest of the Dolomieu & summit & 17 & - & - & 1.3 \\
\hline 22 Aug 2003 & Bory and north flank & $2590-2140$ & 152 & 20 & 125 & 6.2 \\
\hline 30 Sep 2003 & west flank southwest & $2330-2195$ & 65 & 13 & 42 & 1 \\
\hline 7 Dec 2003 & southeast of the Dolomieu & summit & 56 & - & - & 1.2 \\
\hline 9 Jan 2004 & "Plaine Des Osmondes" northeast flank & $1390-1510$ & 2475 & 54 & 2395 & 1.9 \\
\hline
\end{tabular}

${ }^{a}$ Considering the time between the beginning of the seismic swarm and the opening of the first eruptive fissure.

${ }^{b}$ From the beginning of the summit inflation to the beginning of the lateral displacement of the inflation center.

${ }^{\mathrm{c}}$ From the lateral displacement of the inflation center to the opening of the first eruptive fissure. 

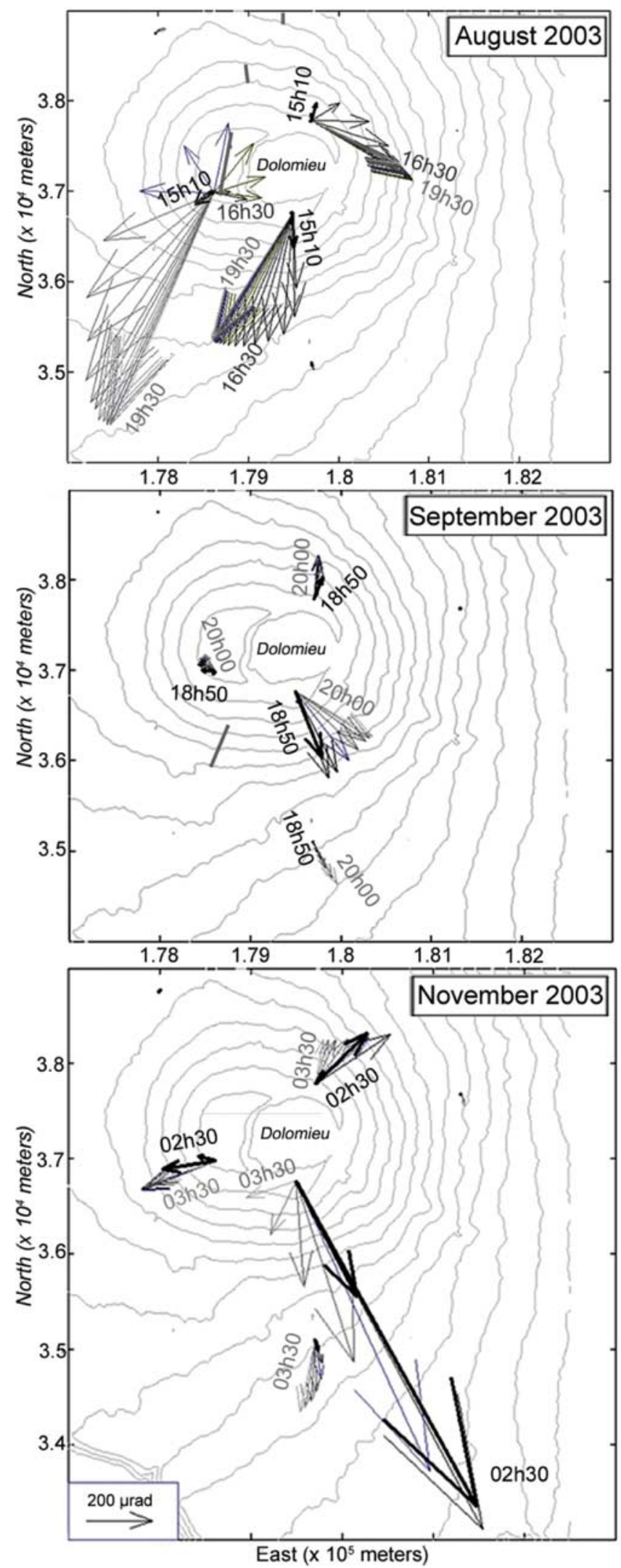

simultaneously with a new uplift of the summit region (Figures 4 and 5).

\subsection{November 2003 Intrusion}

[14] On the morning of the 6 November (at 0200 UTM), another "seismic crisis" started (Figure 5), accompanied by strong surface deformations observed by tiltmeter, extensometer and GPS networks (Figures 4 and 6). GPS measurements between October and end of November 2003 confirmed the surface displacements with a vertical uplift and horizontal movements up to $30 \mathrm{~cm}$ (Figure 7). Surface displacements suggested the location of the deformation source beneath the southeast border of Dolomieu crater. No eruption followed this intrusion but the inflation continued until 7 December with the largest amplitude at the Dolo station (Figure 8).

\subsection{December 2003 Eruption}

[15] On 7 December at 1029 UTM, a "seismic crisis" started (Figure 5) and at 1125 UTM a tremor signal was recorded at all summit seismic stations. The fissure eruption was located in the SE part of Dolomieu crater and a second fissure opened south of Dolomieu emitting gas (Figure 2 and Table 1). No significant amount of lava was erupted from the second fissure. The eruption continued within Dolomieu crater until 25 December.

\section{Modeling and Inversion Method}

[16] On the basis of the geological setting, the deformation field and the location of the earthquake hypocenters introduced above, we model the slight intereruptive ground deformation by an overpressurized shallow magma reservoir, whereas the rapid timescale deformations associated with eruptive fissures are modeled as dike injections.

[17] Tiltmeter and GPS data are modeled by deformation sources embedded in a three-dimensional elastic half-space employing a mixed boundary element method [Cayol and Cornet, 1998]. The code developed by Cayol and Cornet [1998] takes into account the real topography, the shape of the magma chamber and/or one or several dikes. The code is based on a combination of two boundary element methods: the direct method and the displacement discontinuity method. The direct method is appropriate to model massive structures like topography and magma chamber, while the displacement discontinuity method allows modeling fractures and dikes. For the calculation, the edifice is assumed to be elastic, homogeneous and isotropic with a Young's modulus of $5 \mathrm{GPa}$ [Cayol and Cornet, 1998] and a Poisson's ratio of 0.25 . Structures such as topography, dikes and magma chamber are represented by a mesh. For the

Figure 6. Tilt variations observed within a $10 \mathrm{~min}$ time window, (top) from 1400 to 1930 UTM for the August 2003 dike intrusion, (middle) from 1830 to 2000 UTM for the September 2003 dike intrusion, and (bottom) from 0200 to 0330 UTM for the November 2003 intrusion. Vectors are oriented in direction of the slope increase. Bold solid vectors represent the tilt variations linked with the first vertical dike migration, and the shade off gray vectors represent evolution of the tilt signal with time. Solid gray lines represent eruptive fissures. 

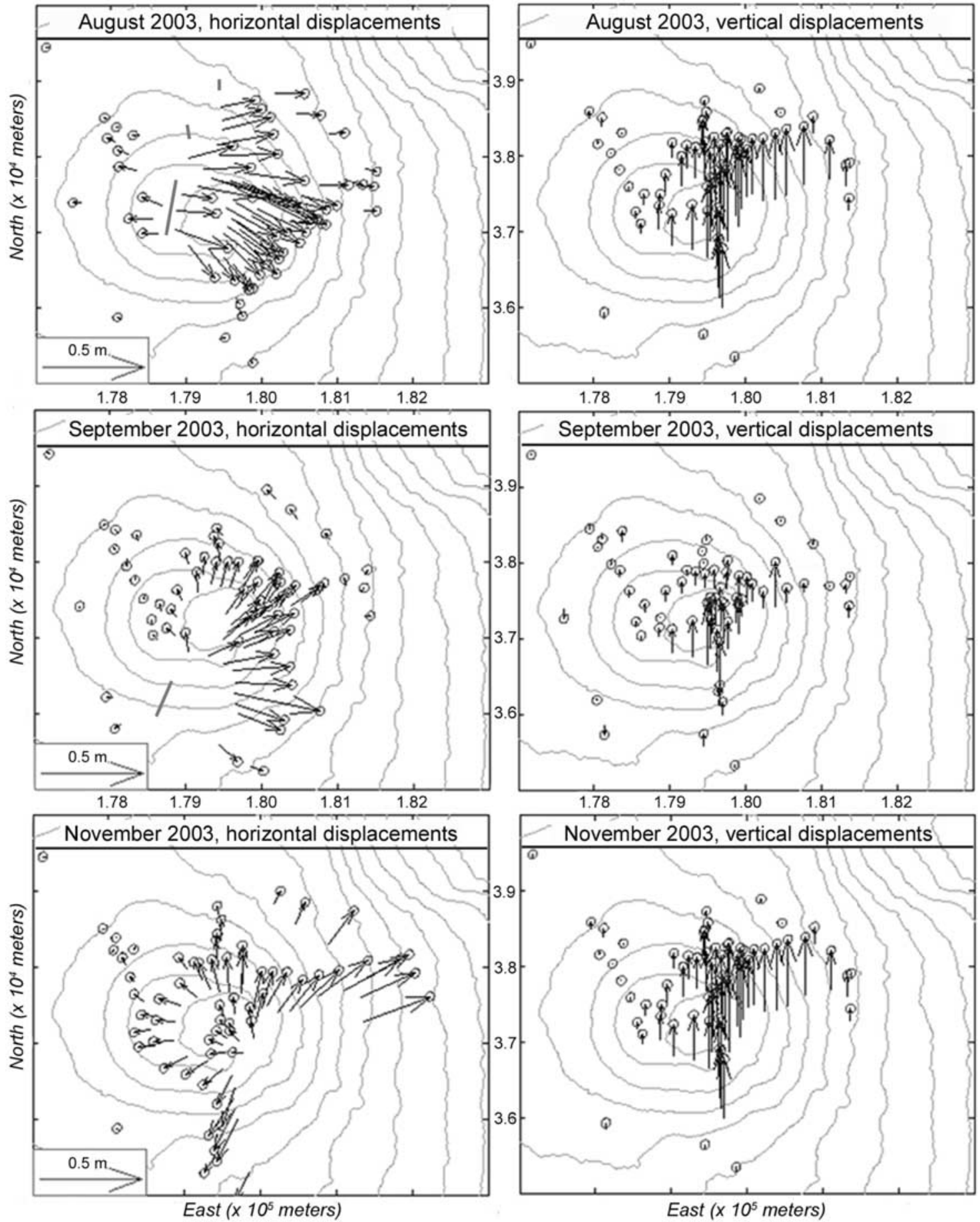

Figure 7. (left) Horizontal and (right) vertical displacements (top) between early August and early September 2003, (middle) between early September and October, and (bottom) between early October and early November recorded by GPS. The GPS campaigns took place on 4, 5, 7, 8 and 14 August; on 2, 10, 22, 25 and 25 September; on 8, 9, 14, 15, and 21 October; and on 12, 14, 17, 18, 19, and 26 November. Error ellipses are reported. Solid gray lines represent eruptive fissures. 


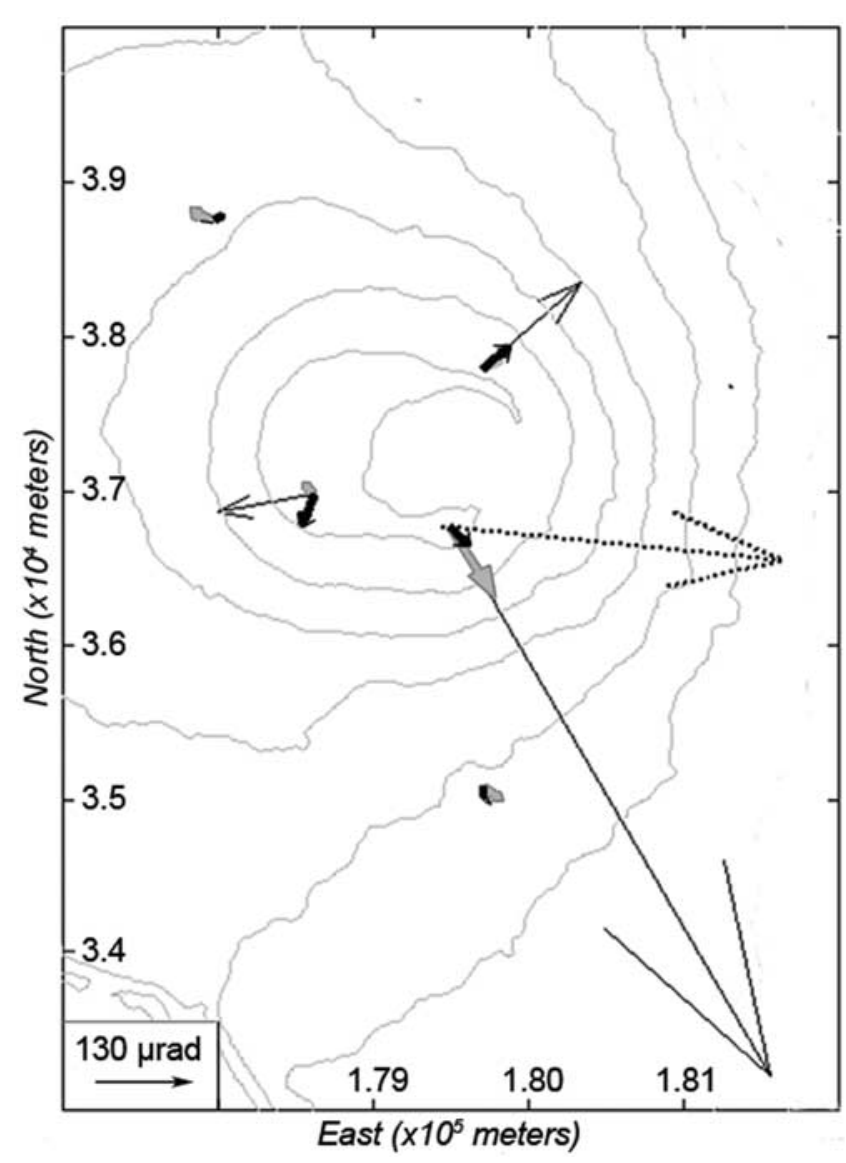

Figure 8. Tilt variations at the end of 2003, during the vertical migration of the 6 November intrusion (black arrows), between 7 November and 6 December (bold gray arrows), and during the 7 December eruption (first stage in bold black and second in dot black).

topography we used a digital elevation model of PdF with a resolution of $25 \mathrm{~m}$ (Figure 9). The displacements are calculated at the nodes of the mesh and at the barycenters of elements connected the fractures to the surface. The modeled dike is divided in two parts, a main part and a shallow prolongation consisting of "en echelon" segments connected to the surface topography at eruptive fissures. Following Fukushima et al. [2005], for the inversion, we used seven parameters to define the properties of the dike: dip, bottom elevation, bottom side inclination, angle between the top and the bottom sides (twist), inclination of the vertical side (shear), the length ratio between the top and the bottom sides, and the overpressure (Figure 9).

[18] Regarding the elongated shape of the Dolomieu crater caused by numerous collapses due to the emptying of the shallow magma chamber [Lénat and Bachèlery, 1990], we decided to model the pressure source between eruption by an ellipsoid defined by its center and half axes (X, Y, Z).

[19] In order to find the best model that matches the field data, we used a neighborhood algorithm, one of the Monte Carlo inversion methods [Sambridge, 1999; Fukushima et al., 2005]. The misfit function we used is the normalized root-mean-square difference between observed and calculated displacements. The neighborhood algorithm then searches the model that minimizes the misfit function in the acceptable parameters range that we have defined.

\section{Results}

\subsection{Overpressure Before Eruption}

[20] We use for the inversion the tilt variations recorded during September just before the eruption. During this period, the six tiltmeters were all operational together allowing us to constrain more precisely the source of pressure.

[21] The best fit model explains $75 \%$ of the tilt signals before the September eruption and locates the source of $3 \mathrm{MPa}$ overpressure at $300 \mathrm{~m}$ above sea level under Dolomieu crater (Figures 10 and 11).

[22] Our model, with the dimensions of $0.2 \mathrm{~km}(\mathrm{Z})$, $0.7 \mathrm{~km}(\mathrm{X}), 0.5 \mathrm{~km}(\mathrm{Y})$, is in good agreement with the volume of $0.35 \mathrm{~km}^{3}$ estimated by Sigmarsson et al. [2005] from $\mathrm{U}$ series disequilibria for the shallow magma chamber.

\subsection{Dynamics of Lateral Dike Propagation}

\subsubsection{August}

[23] Following previous studies [Peltier et al., 2005b], at $\mathrm{PdF}$, the dike propagation toward the flank takes place in two stages: (1) a vertical migration of the dike from the magma chamber centered under the Dolomieu crater and (2) followed by a lateral migration toward the surface.

[24] For the first stage (between 1452 and 1515 UTM), we modeled the vertical migration based on the inversion of the tiltmeter data only, the permanent GPS was not available in a continuous mode at this moment. Then for the second stage, we started from the initial structure of the vertical migration model and the global geometry has been obtained from inversion calculations based on surface displacements of GPS benchmarks measured after the eruption. Since GPS cover a significant geographical extension on the flank, we can constrain the total geometry of the dike better than using only tiltmeters data.

[25] Using this inversion method, we obtained an optimal dike, undergoing a constant overpressure of $1.1 \mathrm{MPa}$, fitting $79 \%$ of the GPS data (both in magnitude and direction). The misfit on the vertical component is the greatest due to the higher errors on this GPS component (Figure 12). The remaining discrepancy can be attributed to the fact that GPS measurements are made several days before and after the eruption and can include a slight part of the preeruptive inflation, and a part of the syneruptive summit deflation (Figure 12). Another explanation for the discrepancy is that the model considers the edifice as homogeneous. Preexisting fracturation on the summit area can lead to heterogeneity and thus to approximation. The modeled dike originates from $400 \mathrm{~m}$ above sea level. The lateral part of the dike has an average dip of $70^{\circ}$ to the east and is connected to the vertical part at $1500 \mathrm{~m}$ above sea level (Figure 12). The opening of the dike at the surface is $30 \mathrm{~cm}$ matching field observations. This modeled lateral part of the dike is in agreement with that found by Froger et al. [2004] using radar interferometry data; however we find a greater dip angle compared to $53^{\circ}$ deduced by Froger et al. [2004]. In order to explain more satisfactorily the Bory tiltmeter signal, 


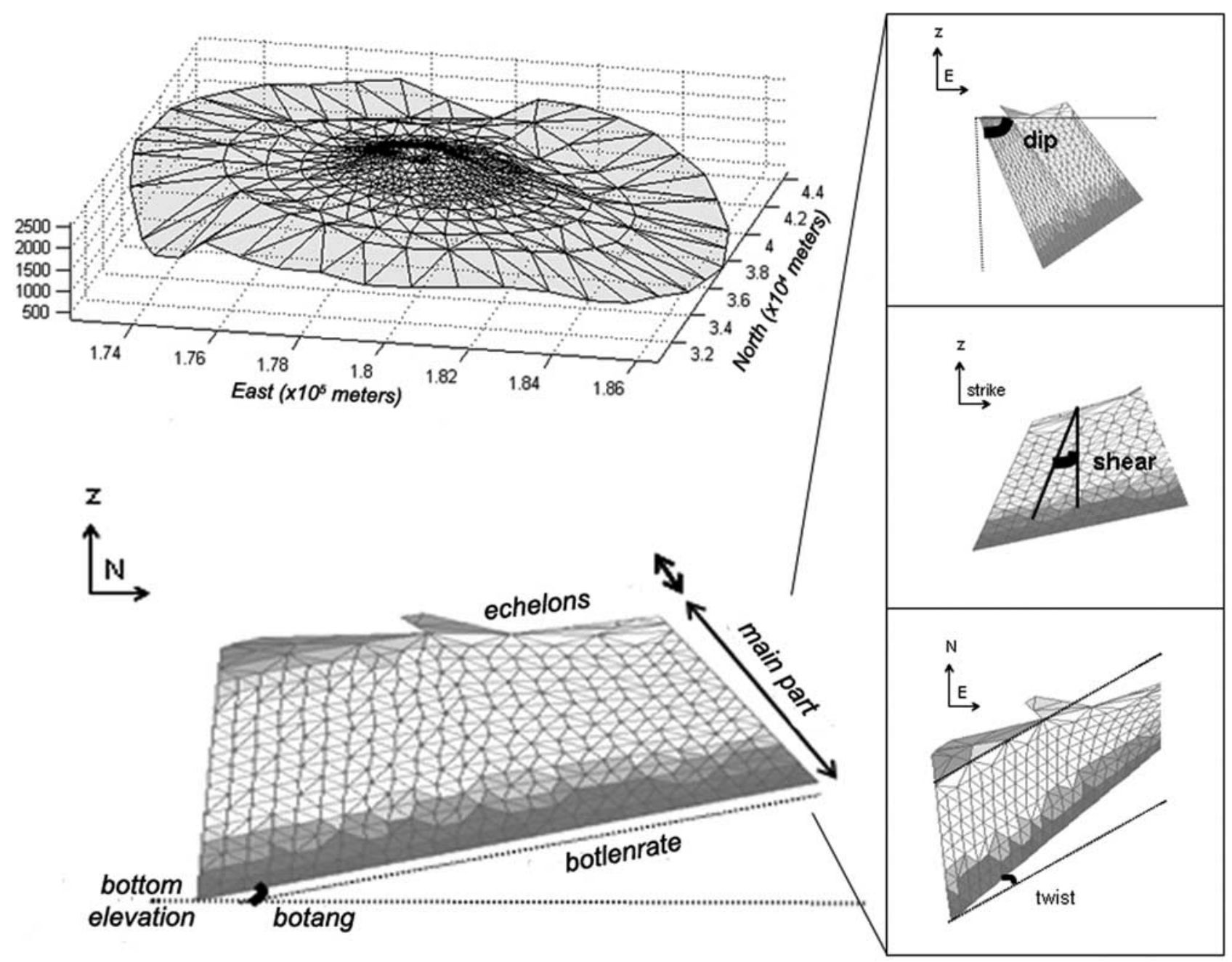

Figure 9. (left) Mesh of the topography and the dike. (right) Parameters defining the geometry of the modeled dike.
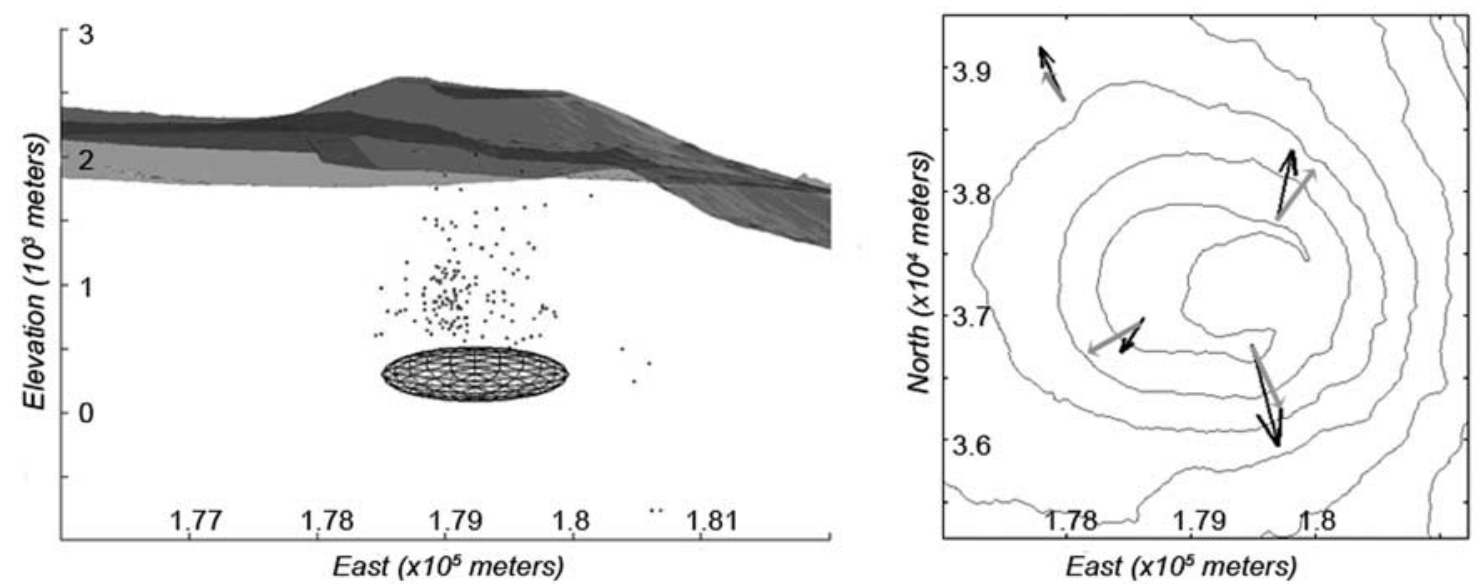

Figure 10. (left) Model of the pressure source inducing deformation before September 2003 eruption (Gauss Laborde Réunion map coordinates). (right) Comparison between observed (black) and calculated (gray) tilt variations associated with this pressure source. Earthquakes hypocenters related to the eruptions of 2003 are located by black points. 

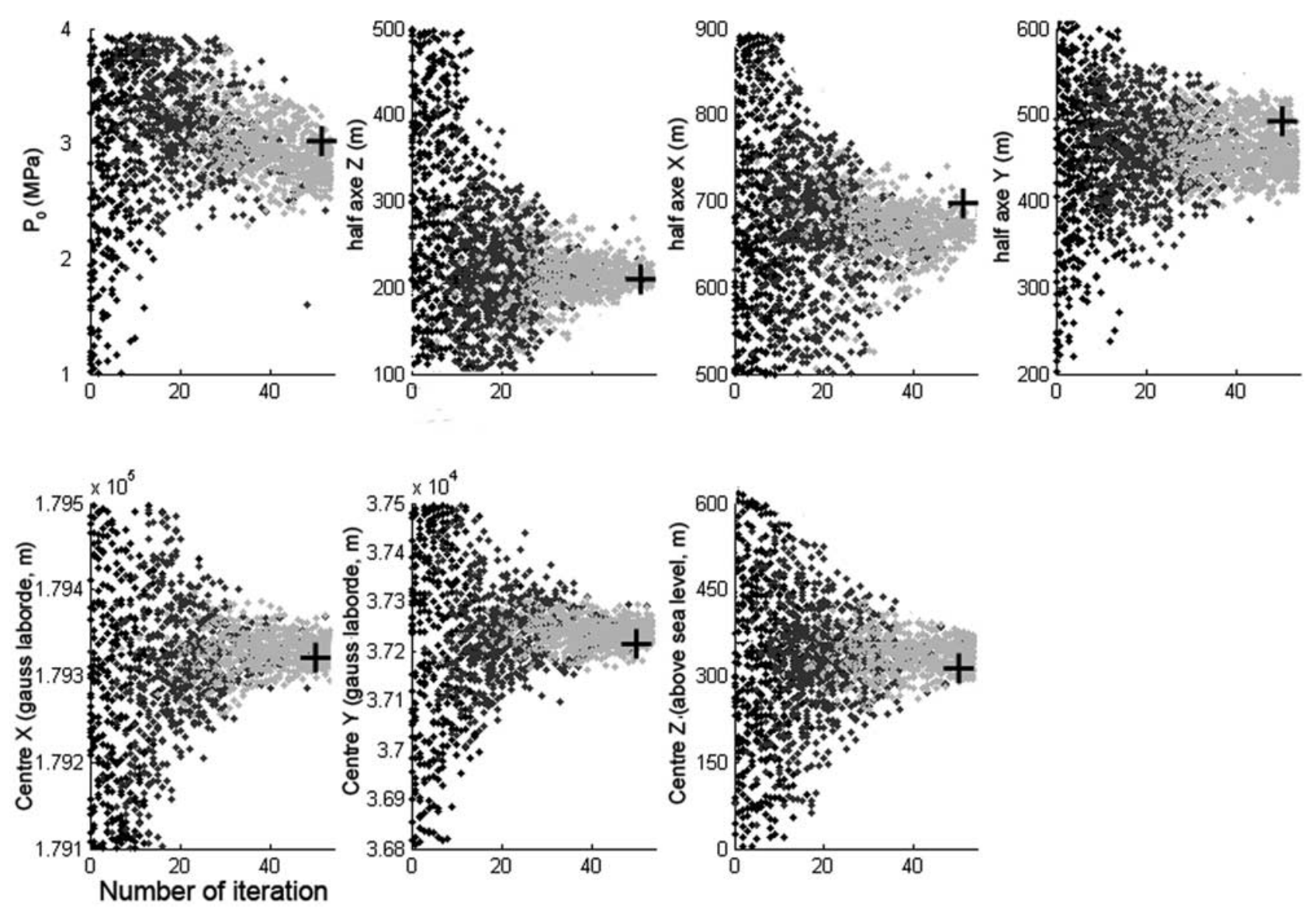

Figure 11. Parameter values plotted against number of iteration. The shade off gray points show the convergence to low-misfit area in the parameters range for the model of the magma chamber. Black crosses represent the optimum solution. 


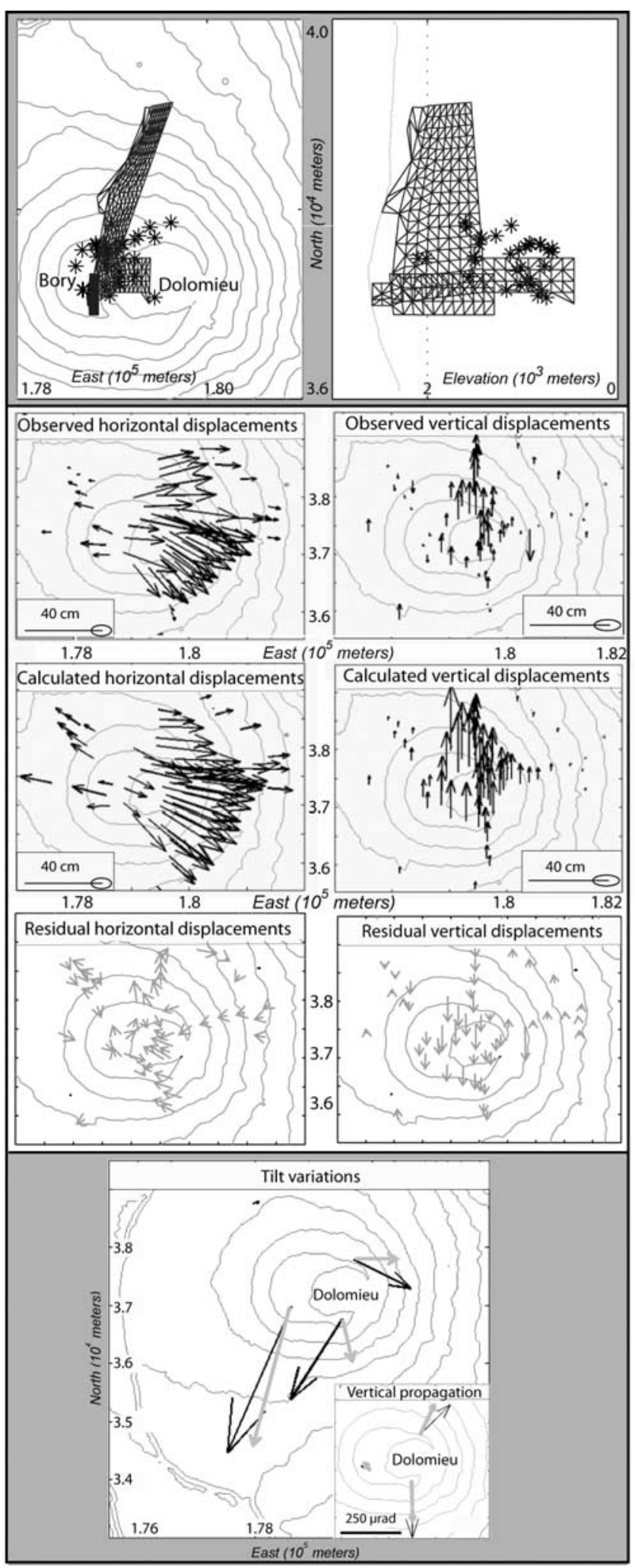

Figure 12. (top) Geometry of the dike modeled for the August 2003 eruption (Gauss Laborde Reunion map coordinates) and (middle) displacements associated; identical scale for the six panels. (bottom) Comparison between observed (black) and calculated (gray) tilt variations. Earthquakes hypocenters related to the seismic swarm prior to the eruption are located by black asterisks. we have considered the presence of another superficial dike feeding the upper eruptive fissure (Figure 11). Composition and rheology of the lava from the upper and the lower fissures are different and thus compatible with the presence of two separate feeding dikes. Geochemical analyses of the basalt from the upper fissure show a lower $\mathrm{MgO}$ wt \% content of 7.62 than the lava from the lower fissures, $\mathrm{MgO}$ wt $\%=10.52$. The presence of this second superficial dike in the deformation model increases the fit of the model ( $85 \%$ of the tilt data explained) with smaller residuals on Bory station and without affecting significantly the signal on tilt stations further away (Figure 12).

[26] Thanks to this model of the intrusive path, we can also determine the evolution of the geometry with time during the propagation to the flank. We modeled sequentially the growth of the main dike including the cumulative tilt variations every $10 \mathrm{~min}$. The time dependence of this sequence was established by changing three parameters with time: the overpressure, the length, and the width of the dike constrained by the final geometry of the dike found earlier. The time sequence presented in Figure 13 is the best fit obtained by the inversion. The ratio of Tuca station tilt to Chaf station tilt gives us a field visualization of the dike propagation. Tuca station is located on the intruded flank, whereas Chaf station is located on the opposite flank. The increase of the tilt signal on the Tuca station compared to the tilt signal on the Chaf station shows the growth and the influence of the dike toward the north flank. The increase of the tilt ratio is similar and thus in agreement with the time sequence of the growth of the dike deduced from modeling (Figure 13). The last part of the time sequence of dike propagation presents greater errors because of the lack of tilt stations on the volcano flank, which does not enable us to constrain well the dike propagation further away.

[27] In summary, our model suggests that vertical migration started at $400 \mathrm{~m}$ above sea level, approximately at the base of the seismic swarm. The dike propagated then quickly $(1.3 \mathrm{~m} / \mathrm{s})$ along a more or less vertical axis, between 1450 and 1515 UTM, when it reached its final height. The lateral propagation to the northern flank begins at $1515 \mathrm{UTM}$ at a velocity of 0.2 to $0.6 \mathrm{~m} / \mathrm{s}$ with a nonlinear expansion (Figure 13). At 1630 UTM, the second dike started its migration toward the surface. The total volume of the two dikes is $1 \times 10^{6} \mathrm{~m}^{3}$. The volume of the emitted lava flows was estimated at $6.21 \times 10^{6} \mathrm{~m}^{3}$.

\subsubsection{September}

[28] For the September eruption, the Chaf extensometer (located at $1200 \mathrm{~m}$ from the eruptive fissure) has been used to constrain the lateral extension of the dike on the flank. A significant opening of $0.29 \mathrm{~mm}$, on the Chaf fracture occurred during the intrusion, while just after the beginning of the eruption the same structure closed linked to a propagation of the dike farther away from the eruptive site [Peltier et al., 2006]. The total geometry of the dike was found by the inversion method based on GPS data (Figure 7). Figures 14 and 15 present geometry and time sequence of dynamic models of dike emplacement associated with this event, which is driven by a pressure of $1.5 \mathrm{MPa}$ that fit $85 \%$ of field data. The remaining discrepancy can be clearly attributed to the preeruptive summit inflation included in the GPS measurements (Figure 14). The total volume of the dike is $0.6 \times 10^{6} \mathrm{~m}^{3}$ and propagates on 

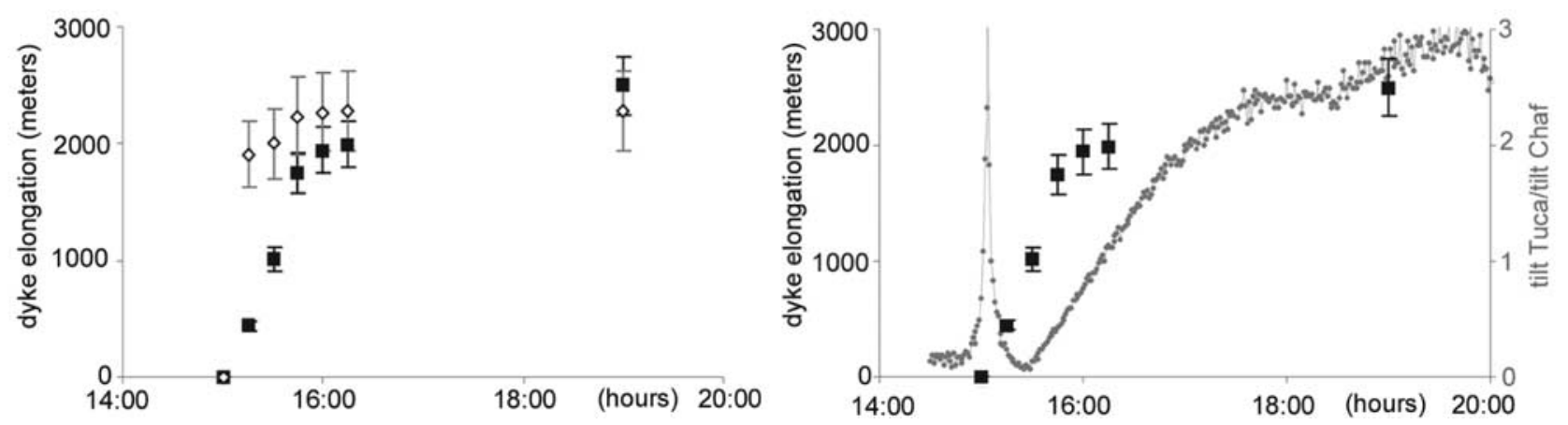

Figure 13. (left) Time sequence of the propagation of the August 2003 main dike: evolution of the height (white diamond) and the length (black square) of the dike with time. (right) Comparison between the model: evolution of the length of the dike during its propagation (black square); and field data: the ratio of Tuca station tilt to Chaf station tilt (gray circle).

the flank at a velocity comprised between 0.4 and $0.6 \mathrm{~m} / \mathrm{s}$. The volume of the lava flows was estimated at $1 \times 10^{6} \mathrm{~m}^{3}$.

\section{Discussion}

[29] During the considered period, the deformation monitoring show a cycle of long-term summit inflation accompanied by seismicity, explained by an increasing pressure in a magma chamber located under Dolomieu crater at shallow depth. The lack of seismicity observed just above sea level (Figure 3) is part of the evidence supporting the presumed location of the magma chamber and fits our model location. The increase of pressure in the magma chamber in 2003 could be related to magma transfers from depth into the shallow magma chamber. In the absence of any new inflow of magma the increase of pressure could be caused by the development of volatile vesiculation at the roof of the chamber associated with the crystallization in the chamber [Tait et al., 1989].

[30] If we consider that the present-day magma would only derive from the 1998 refilling [Battaglia et al., 2005], we should observe more and more differentiated magma with time, as observed during the period 1977-1992 [Bachèlery, 1999]. However, since the 1998 eruption, geochemical analyses (whole rock composition) show a very slight increase of the $\mathrm{MgO}$ value, revealing no magma differentiation [Peltier et al., 2005a]. Such behavior would be more concordant with a regular feeding of the superficial magma chamber which prevents differentiation. The lack of deep seismicity imaging this feeding of a shallow magma chamber can be explained by the presence of a warm opened conduit or by a slow and undetectable migration of magma [Dzurisin, 2003]. At Kilauea, aseismic magma transport prevails also, and aseismic regions connecting the seismic sources along the expected magma paths may be relatively open, low-stress passages in which magma can maintain a state of quasi-steady flow that does not generate measurable seismic signals [Wright and Klein, 2006]. According to this hypothesis, we would presently have a regular magma inflow into the shallow magma chamber generating a nonuniform distribution of the stresses and triggering the preferential rupture of one or an other part of the magma system depending also on the stress distribution linked with the previous magma injections.

[31] Such continuous overpressure could explain the large number of eruptions/intrusion which occurred in 2003, with the first event in May 2003 inside the December 2002 collapse area in the western part of the Dolomieu. This southwest border of the Dolomieu crater seems to play a significant role in the magma transit toward the surface (Figure 16). Since the 1950s this zone is very active with numerous eruptions (1961, 1986, 1992, 2003, and 2005) and collapses $(1953,2002)$. Note that the first inflation centers for the August and September eruptions have also been located in this area (Figures 6, 12, and 14), revealing that the feeding dikes starting from the magma chamber would take this preferential pathway in their first stage of propagation toward the surface. This pathway would correspond to the faults adjacent to the Dolomieu collapse (Figure 16). These faults represent the favored sites for syncollapse to postcollapse eruptions [Roche et al., 2001]. Note that the high velocity $(1.33 \mathrm{~m} / \mathrm{s}$ for the vertical migration in August and $1.15 \mathrm{~m} / \mathrm{s}$ for September) of the first vertical magma migration deduced from its duration and the vertical extension of the dike can be easily explained by this opened pathway.

[32] After this first eruption of the 2003 year, two lateral eruptions took place, following the same general scheme. For the August eruption, two dikes would be implicated, one feeding the upper fissure in the Bory crater and the other feeding the lower fissures. The start of the upper dike would be triggered by the overpressure generated around a

Figure 14. (top) Geometry of the dike modeled for the September 2003 eruption. (Gauss Laborde Reunion map coordinates) and (middle) displacements associated; identical scale for the six panels. (bottom) Comparison between observed (black) and calculated (gray) tilt variations. Earthquakes hypocenters related to the seismic swarm prior to the eruption are located by black asterisks. 

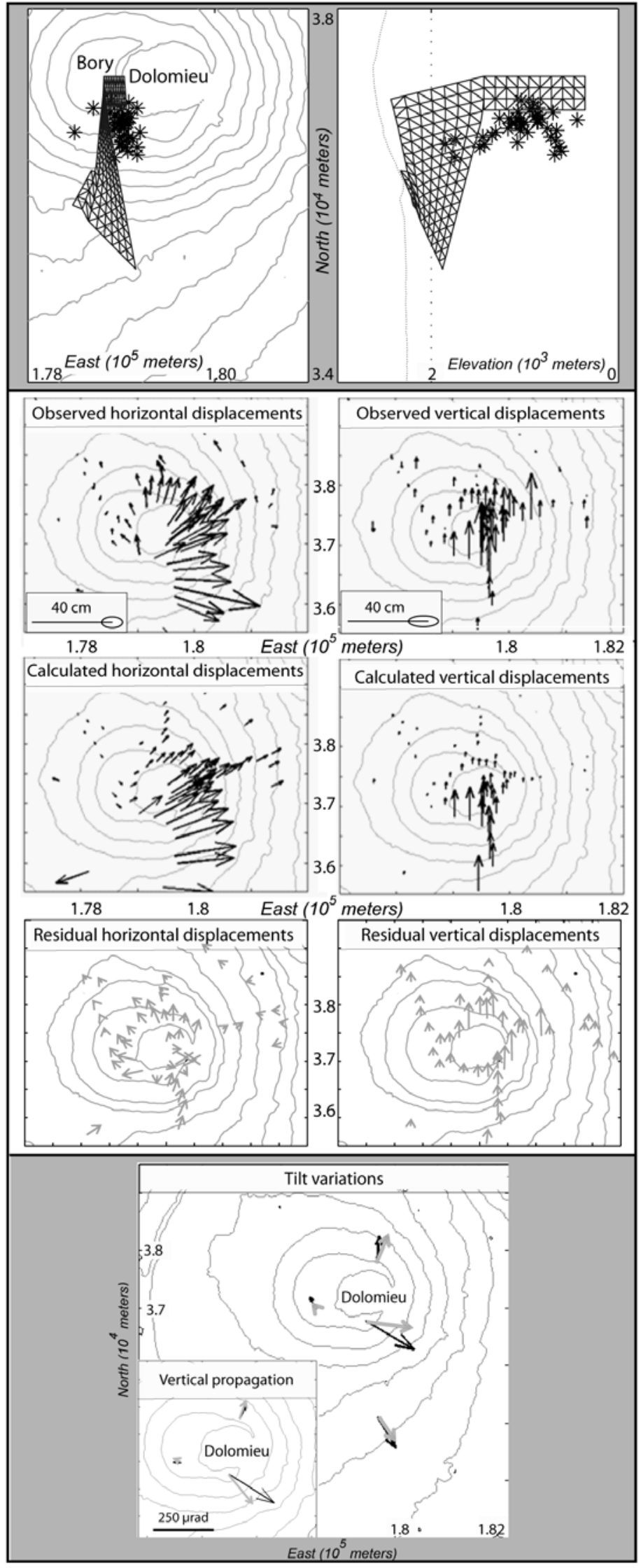

Figure 14

13 of 16 

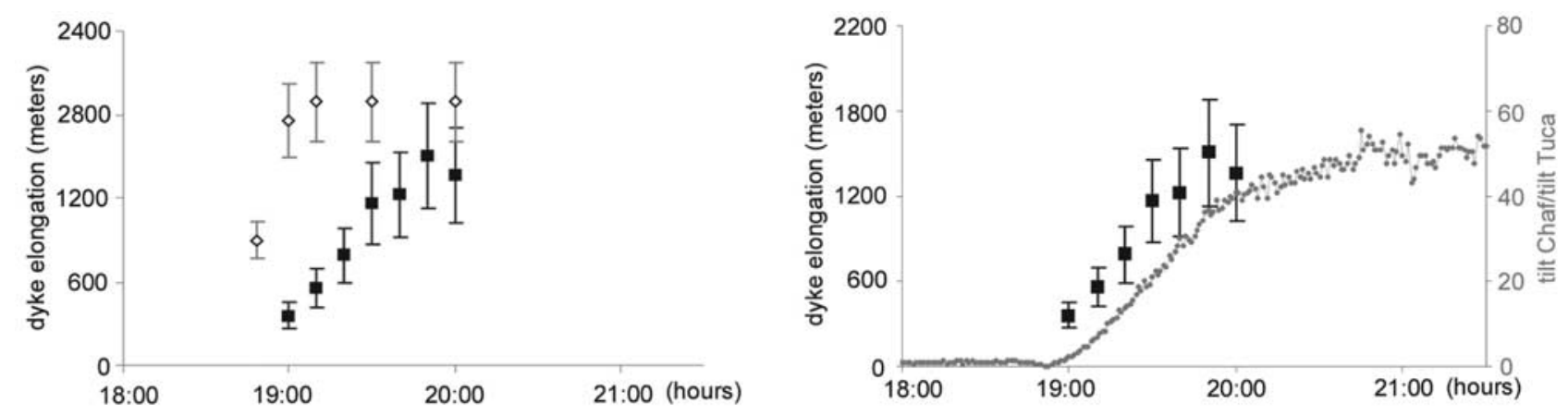

Figure 15. (left) Time sequence of the September 2003 dike propagation: evolution of the height (white diamond) and the length (black square) of the dike with time. (right) Comparison between the model: evolution of the length of the dike during its propagation (black square); and field data: the ratio of Chaf station tilt to Tuca station tilt (gray circle).

residual magmatic pocket of May-June 2003 eruption, explaining a low emission of pahoehoe lava flows (less than $0.01 \mathrm{~km}^{3}$ covering the floor of the Bory crater). The May eruption was located in the southwest part of the Dolomieu crater not far away from this first fissure and ended one and half months before. The dikes feeding the two lateral eruptions originate and propagate first vertically under the Dolomieu crater. Their roots were located in magma chamber at $400 \mathrm{~m}$ above sea level (asl) for the August eruption and $300 \mathrm{~m}$ asl for the September eruption (Figures 12 and 14). These deep roots can explain the delay between the beginning of the seismic crises and the onset of tilt variations (typically $3-5 \mathrm{~min}$ ). The dike needs to reach a shallower level to generate strong ground deformation. When the dike grows toward the surface, intensity of the tilt increases and the direction of vectors stabilizes, defining an inflation center in the vicinity of the Dolomieu crater. Twenty minutes after the beginning of the August eruption and 13 min after the beginning of the September eruption the dike migrated to the north and south flank, respectively, at a velocity between 0.2 and $0.8 \mathrm{~m} / \mathrm{s}$. During the first stage of the lateral migration, the dikes quickly reach their final height (Figures 13 and 15) explaining that the intensity of the tilt remains high and constant. During the lateral migration, we just observe a change in orientation of the tilt vectors (Figure 6). Dikes propagate parallel to the maximum compression axes $\sigma 1$ within cone, $\sigma 1$ is vertical at depth favoring the vertical migration and become parallel near the surface [Van Wyk de Vries and Matela, 1998] directing the propagation to the flank along preexisting fractures.

[33] High estimated velocities for dike propagations for August but also for September are in good agreement with previous studies [Toutain et al., 1992; Peltier et al., 2005b] and can be explained by the dense network of radial and tangential fractures affecting the summit cone of $\mathrm{PdF}$ volcano. The fractures along the rift zones offer preferential pathways for the magmatic intrusions to start its lateral migration [Peltier et al., 2005b]. A dike injection leads to an eruption if the local stresses along the potential pathway are favorable for the propagation of magma-driven fractures up to the surface [Gudmundsson and Brenner, 2004]. In fractured rocks, dike propagation can be affected by

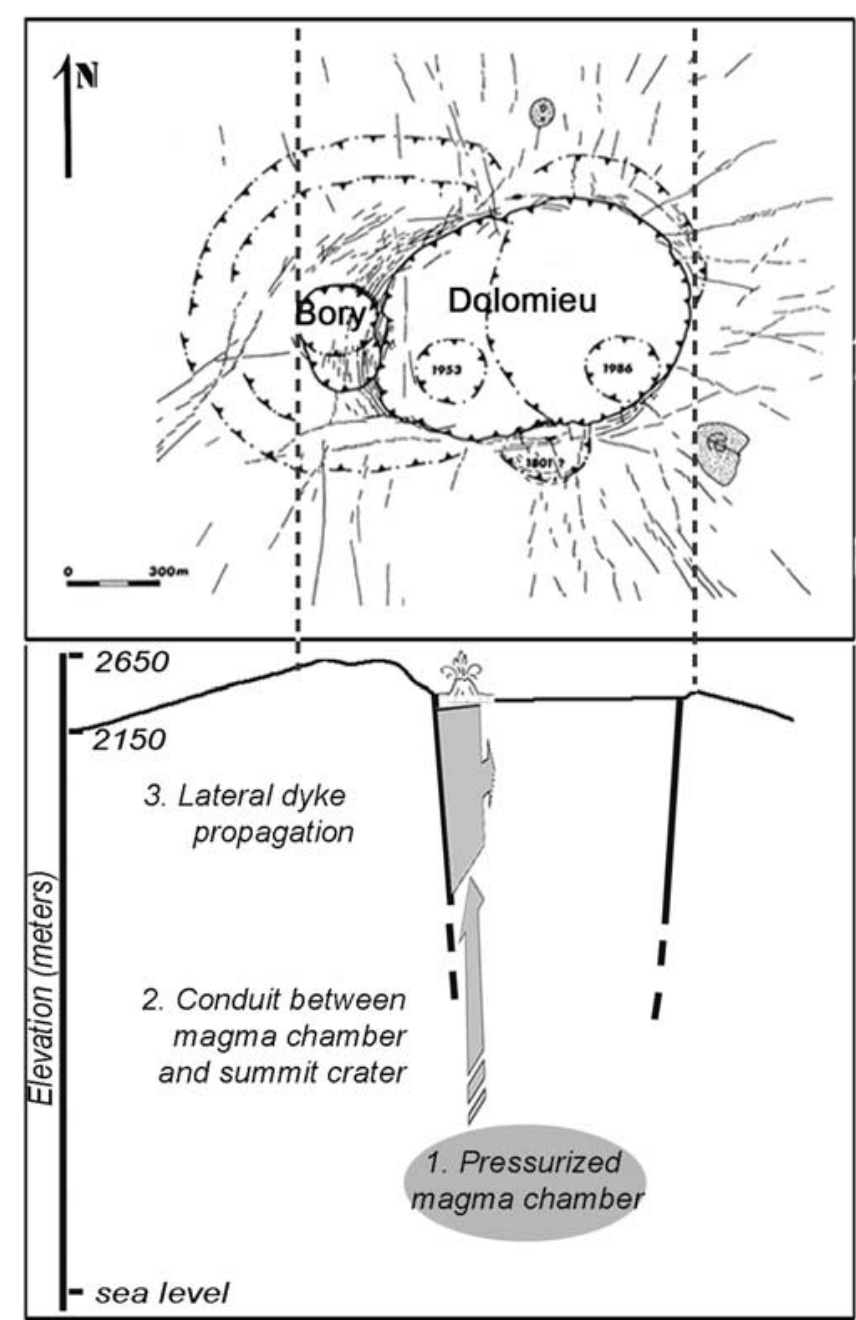

Figure 16. Global scheme of eruptive dynamics at Piton de La Fournaise volcano in May, August, and September 2003, and implication of the preexisting fracturation (map of fracturation (black line) and old limits of crater (dotted lines with triangles) according to Bachèlery [1999]). The numbered phrases refer to the text. 
changes in the Young's modulus. A weaker Young's modulus tends to release the stresses around the tip of the fracture and guides the injection [Gudmundsson and Loetveit, 2005]. Thus, as soon as an ascending dike meets a network of lateral fractures, it tends to divert and to migrate laterally to the flank, explaining the eruptive fissure locations along the two main rifts zones. The start of the lateral migrations at shallow depth $(1500 \mathrm{~m}$ asl in August) reveals thus a structural control in the upper levels of the edifice (Figures 12 and 14). Preexisting fractures do not permanently emit gas or steam, revealing no direct connection between fractures and the magma feeding system. This behavior might indicate that these opened fractures are not very deep, and influence the dike orientation at shallow level.

[34] After the eruptions of May, August, and September a new magma intrusion occurred in November, but in this case the dike stopped at depth under the southeast flank of the summit cone (Figures 2 and 7). Gudmundsson and Brenner [2004] indicate that dike arrests are primarily controlled by the local stresses in the layers through which the dikes propagate. The southeastern area of the summit has shown several dike arrests since observations started in 1980 [Lénat et al., 1989; Bachèlery, 1999]. This part of the volcano corresponds to a "rigid" unit, not intensively fracturated which would not favor dike propagation (Figure 16). Few eruptions have taken place in this area, and have always emitted high volumes of magma, indicating stronger pressure involved in the magma migration to reach the surface. In November 2003, a low driving pressure and the lack of preexisting fractures in this area can explain the dike arrest. The location of the following December eruption near this intrusive area and the fact that the summit inflation started again just after the November event with a predominant tilt signal on Dolo station could imply a relation between these two events (Figure 8). The first inflation centers of the November and December dike propagation and the inflation recorded between these two events are similar (below the south of Dolomieu crater), the intensity of the tilt changes but not the orientation. This tilt behavior at the end of 2003 and the location of the seismic swarm below the south rim of the Dolomieu crater (Figure 3) during the two seismic crises preceding the November intrusion and the December eruption, suggest the same pattern for these two events. The December eruption could be triggered by a new overpressure below the south part of the Dolomieu during November linked with the presence of this intrusion, allowing the dike to propagate below the fractured east part of the Dolomieu (Figure 16). This cycle of activity ended in early January 2004 with an eruption which occurred $4 \mathrm{~km}$ away from the cone in "La Plaine des Osmondes" on the north flank (Figure 1 and Table 1).

\section{Conclusion}

[35] For the studied period, the long-term deformations in the summit area of the PdF volcano were continuous, just interrupted by rapid and strong deformation during magma injections. Using a 3-D elastic model, and including both displacements and tilt observations in an inversion process, we propose an interpretation of the displacement field and provide some constraints on the magma chamber at PdF, and on the geometry and spatial-temporal evolution of propagating dikes feeding lateral eruptions. Magmatic processes associated with eruptions of PdF can be summarized as follows (Figure 16): (1) The summit and lateral eruptions in 2003 were fed from a common magma chamber located at a depth of $300 \mathrm{~m}$ asl beneath summit and undergoing a continuous overpressure throughout this period. (2) The vertical conduit between the magma chamber and the summit crater was established during the December 2002 collapse and filled as magma rose into it, leading to the initial summit eruption in May. (3) For the two lateral eruptions of August and September 2003, dikes have taken also this vertical pathway at a velocity of 1.1 to $1.3 \mathrm{~m} / \mathrm{s}$ before intruding the flank quickly at a velocity of 0.2 to $0.8 \mathrm{~m} / \mathrm{s}$.

[36] Acknowledgments. We are grateful to V. Cayol and Y. Fukushima, for providing the source code and the neighborhoood algorithm code, respectively, and for their help. Thanks to Valérie Ferrazzini for the seismic data and the staff of the Piton de La Fournaise Volcanological Observatory for their help in providing deformation data. We also thank J. Neuberg for improvements of this paper and Stephanie Prejean and two anonymous reviewers for helpful review comments.

\section{References}

Bachèlery, P. (1999), Le Fonctionnement des volcans boucliers, Habilitation à Diriger des Recherches thesis, 698 pp., Univ. de la Reunion, Saint Denis, France.

Battaglia, J., and P. Bachèlery (2003), Dynamic dyke propagation deduced from tilt variations preceding the March 9, 1998, eruption of the Piton de la Fournaise volcano, J. Volcanol. Geotherm. Res., 120, 289-310.

Battaglia, J., V. Ferrazzini, T. Staudacher, K. Aki, and J.-L. Cheminée (2005), Pre-eruptive migration of earthquakes at the Piton de La Fournaise volcano (Réunion Island), Geophys. J. Int., 161, 549-558.

Blum, P.-A, J.-L. Bordes, B. Groguel, and A. Magouarou (1991), Performances and applications of a very high resolution tiltmeter, in Field Measurements in Geotechnics, pp. 139-151, A. A. Balkema, Brookfield, Vt.

Bonaccorso, A., M. Aloisi, and M. Mattia (2002), Dike emplacement forerunning the Etna July 2001 eruption modeled through continuous tilt and GPS data, Geophys. Res. Lett., 29(13), 1624, doi:10.1029/ 2001 GL014397.

Cayol, V., and F. H. Cornet (1997), 3D mixed boundary elements for elastostatic deformation field analysis, Int. J. Rock Mech. Min. Sci., 34, $275-287$.

Cayol, V., and F. H. Cornet (1998), Three-dimensional modelling of the 1983-1984 eruption at Piton de La Fournaise volcano, Reunion Island, J. Geophys. Res., 103, 18,025-18,037.

Cervelli, P., P. Segall, F. Amelung, H. Garbeil, C. Meertens, S. Owen, A. Mikilius, and M. Lisowski (2002), The 12 September 1999 upper east rift zone dike intrusion at Kilauea volcano, Hawaii, J. Geophys. Res., 107(B7), 2150, doi:10.1029/2001JB000602.

Coppola, D., T. Staudacher, and C. Cigolini (2005), The May-July 2003 eruption at Piton de la Fournaise (La Réunion): Volume, effusion rates, and emplacement mechanisms inferred from thermal imaging and global position system (GPS) survey, in Kinematics and Dynamics of Lava Flows, edited by M. Manga and G. Ventura, Spec. Pap. Geol. Soc. Am., 396, 103-124, doi:10.1130/2005.2396 (08).

Dzurisin, D. (2003), A comprehensive approach to monitoring volcano deformation as a window on the eruption cycle, Rev. Geophys., 41(1), 1001, doi:10.1029/2001RG000107.

Froger, J.-L., Y. Fukushima, P. Briole, T. Staudacher, T. Souriot, and N. Villeneuve (2004), The deformation field of the August 2003 eruption at Piton de la Fournaise, Reunion Island, mapped by ASAR interferometry, Geophys. Res. Lett., 31, L14601, doi:10.1029/2004GL020479.

Fukushima, Y., V. Cayol, and P. Durand (2005), Finding realistic dike models from interferometric synthetic aperture radar data: The February 2000 eruption at Piton de La Fournaise, J. Geophys. Res., 110, B03206, doi:10.1029/2004JB003268.

Gudmundsson, A., and S. L. Brenner (2004), How mechanical layering affects local stresses, unrests, and eruptions of volcanoes, Geophys. Res. Lett., 31, L16606, doi:10.1029/2004GL020083.

Gudmundsson, A., and I. F. Loetveit (2005), Dyke emplacement in a layered and faulted rift zone, J. Volcanol. Geotherm. Res., 144, 311-327. 
Lénat, J.-F., and P. Bachèlery (1990), Structure et fonctionnement de la zone centrale du Piton de La Fournaise, in Le Volcanisme de La Réunion, edited by J.-F. Lénat, pp. 257-296, Cent. de Rech. Volcanol., ClermontFerrand, France.

Lénat, J. F., P. Bachèlery, A. Bonneville, and A. Hirn (1989), The beginning of the 1985-1987 eruptive cycle at Piton de La Fournaise (La Reunion) New insights in the magmatic and volcano-tectonic systems, J. Volcanol. Geotherm. Res., 36, 209-232.

Longpré, M. A., T. Staudacher, and J. Stix (2006), The November 2002 eruption at Piton de La Fournaise volcano, La Reunion Island: Ground deformation, seismicity, and pit crater collapse, Bull. Volcanol., 69, 511-525, doi:10.1007/s00445-006-0087-0.

Nercessian, A., A. Hirn, J.-C. Lépine, and M. Sapin (1996), Internal structure of Piton de La Fournaise volcano from seismic wave propagation and earthquakes distribution, J. Volcanol. Geotherm. Res., 70, $123-143$

Peltier, A., T. Staudacher, V. Ferrazzini, and P. Bachèlery (2005a), Evolution of Piton de La Fournaise activity and multi discipline monitoring of eruptions between 1999 and 2004, Geophys. Res. Abstr., 7, Abstract 06,035 .

Peltier, A., V. Ferrazzini, T. Staudacher, and P. Bachèlery (2005b), Imaging the dynamics of dyke propagation prior to the 2000-2003 flank eruptions at Piton de La Fournaise, Reunion Island, Geophys. Res. Lett., 32 , L22302, doi:10.1029/2005GL023720.

Peltier, A., T. Staudacher, P. Catherine, L. P. Ricard, P. Kowalski, and P. Bachèlery (2006), Subtle precursors of volcanic eruptions at Piton de La Fournaise detected by extensometers, Geophys. Res. Lett., 33, L06315, doi:10.1029/2005GL025495.

Roche, O., B. van Wyk de Vries, and T. H. Druitt (2001), Sub-surface structures and collapse mechanisms of summit pit craters, J. Volcanol. Geotherm. Res., 105, 1-18.
Sambridge, M. (1999), Geophysical inversion with a neighbourhood algorithm-Searching a parameter space, Geophys. J. Int., 138, $479-494$.

Sigmarsson, O., M. Condamines, and P. Bachèlery (2005), Magma residence time beneath the Piton de La Fournaise volcano, Reunion Island, from U-series disequilibria, Earth Planet. Sci. Lett., 234, $223-$ 234.

Staudacher, T., A. Peltier, V. Ferrazzini, and P. Bachèlery (2004), 22 August 2003 eruption at Piton de la Fournaise, Reunion Island GPS extensometer and tiltmeter measurements and seismicity, paper presented at IAVCEI 2004, Int. Assoc. of Volcanol. and Chem. of the Earth's Inter. Pucon, Chile.

Tait, S., C. Jaupart, and S. Vergniolle (1989), Pressure, gas content and eruption periodicity of a shallow, crystallizing magma chamber, Earth Planet. Sci. Lett., 92, 107-123.

Toutain, J.-P., P. Bachelery, P.-A. Blum, J. L. Cheminee, H. Delorme, L. Fontaine, P. Kowalski, and P. Taochy (1992), Real time monitoring of vertical ground deformations during eruptions at Piton de la Fournaise, Geophys. Res. Lett., 19, 553-556.

Wright, T. L., and F. W. Klein (2006), Deep magma transport at Kilauea volcano, Hawaii, Lithos, 87, 50-79.

Van Wyk de Vries, B., and R. Matela (1998), Styles of volcano-induced deformation: Numerical models of substratum flexure, spreading and extrusion, J. Volcanol. Geotherm. Res., 81, 1-18.

P. Bachèlery and A. Peltier, LSTUR/IPGP UMR7154, 15 avenue René Cassin, BP 7151, F-97715 Saint-Denis messag cedex 9, France. (bachel@univ-reunion.fr; peltier@univ-reunion.fr)

T. Staudacher, OVPF/IPGP UMR7154, le 27ème km, F-97418 La Plaine des Cafres, France. (staud@univ-reunion.fr) 